\title{
Impact of Cultivation Technologies on Soybean Production and Quality
}

\author{
Inga Jansone \\ dept. of Plant breeding and \\ Agroecology \\ Institute of Agricultural Resources \\ and Economics \\ Dižstende, Latvia \\ inga.jansone@arei.lv \\ Aldis Stramkalis \\ dept. of Plant breeding and \\ Agroecology \\ Institute of Agricultural Resources \\ and Economics \\ Viḷani, Latvia \\ aldis.stramkalis@arei.lv
}

\author{
Vita Sterna \\ dept. of Plant breeding and \\ Agroecology \\ Institute of Agricultural Resources \\ and Economics \\ Dižstende, Latvia \\ vita.sterna@arei.lv \\ Arnis Justs \\ dept. of Plant breeding and \\ Agroecology \\ Institute of Agricultural Resources \\ and Economics \\ Viḷani, Latvia \\ arnis.justs@arei.lv
}

\author{
Veneranda Stramkale \\ dept. of Plant breeding and \\ Agroecology \\ Institute of Agricultural Resources \\ and Economics \\ Vilani, Latvia \\ veneranda.stramkale@arei.lv \\ Sanita Zute \\ dept. of Plant breeding and \\ Agroecology \\ Institute of Agricultural Resources \\ and Economics \\ Dižstende, Latvia \\ sanita.zute@arei.lv
}

\begin{abstract}
Legumes are considered the second most important food source after cereals. One of high protein legume - soybeans is new species for growing in Latvia. Biochemical composition of soybeans is variable dependent on varieties, and highly affected by environmental factors, including fertilisation and the presence of Rhizobium bacteria. Therefore, the present study was conducted to evaluate a chemical composition of soya (Glycine max $\mathbf{L}$ ) differently fertilized and grown in different places in Latvia. In this study was evaluated protein, fat, fibre content and yield of soybean variety 'Laulema' grown at different (F1F6) fertilisation background in Stende and Vilani. Overall results of a three-year analysis (2018-2020) showed that the protein content of soybean 'Laulema' ranged from 31.0 to $38.9 \%$, values of total crude fat ranged from 19.4 to 22.4 , but crude fibre 10.5-13.7\%. Significant difference was observed among fertilisation background, year and climatic conditions. Soybean productivity depends to a large extent on climatic conditions. Providing favourable conditions for the development of Rhizobium bacteria and the availability of balanced nutrients for plants, soybean yield can reach 2 $3 \mathbf{t ~ h a}^{-2}$ also in Latvia
\end{abstract}

Keywords - soybean, feed, food, fertilisation, protein.

\section{INTRODUCTION}

Soybean seed is one of the most important protein sources for human and livestock all over the world. In the EU this crop is produced mainly in Italy (33\%), Romania (18\%), Croatia (14\%), Austria, Hungary and France (all 9\%) [1].

Safety and sustainability of the food system can be guaranteed by increasing the locally grown raw material and thus allowing to reduce the amount of imported soy products (which is not always GMO free). Soybean adaptation in Baltic / Nordic region is a new opportunity and challenge resulting from climate change. This is evidenced by the increase in soybean sown areas in recent years in Lithuania to 2,100 and in Latvia - 298 ha [2]. The EU green policy emphasizes the efficient and sustainable use of plant genetic resources to reduce soybean imports and increase the self-sufficiency of this crop. Currently, EU countries produce only $5-7 \%$ of total soy protein consumption [3]. There is a great demand for GMO-free soy, especially soy that is grown using organic farming practices. 
Several factors influence the chemical composition present in soybean seeds, such as climatic changes, genetics, and soil fertility [4],[5]. Next to the climatic factors, adverse soil conditions are major constraints for soybean production. Board and Kahlon [6] suggested thad recent yield gains in the USA are $50 \%$ due to cultivar genetic improvement and $50 \%$ to improve cultural practices.

Therefore aim of this study was evaluate different cultivation technologies for improwing soybean yield and quality.

\section{MATERIALS AND METHODS}

The field trials were set up at the Research Center of the Institute of Agricultural Resources and Economics in Stende $\left(57^{\circ} 11^{\prime} 20^{\prime \prime} \mathrm{N}, 22^{\circ} 33^{\prime} 43^{\prime \prime} \mathrm{E}\right)$ and at the Latgale Agricultural Research Center Ltd. in Vilani (56 $34^{\prime} 10^{\prime \prime} \mathrm{N}$, $26^{\circ} 58^{\prime} 01^{\prime \prime E}$ ) from 2018 to 2020 year.

Experimental design and treatments. Two soybean cultivars were used in the experiment (corresponding to 000 group by vegetation period) - 'Laulema' (Estonia) and 'Lajma' (Poland). Field experiments were carried out using a block design with four replicates and plot size was $20 \mathrm{~m}^{2}$. The sowing rate used was 50 germinating seeds per $\mathrm{m}^{2}$, row party distance $25 \mathrm{~cm}$. The seeds were treated with Rhizobium bacterial product HiStick ${ }^{\circledR}$ before sowing.

The soil type and characteristic of experimental fields assumed in table 1.

TABLE 1 THE SOIL TYPE AND CHARACTERISTIC IN EXPERIMENTAL FIELDS IN STENDE AND VIANI

\begin{tabular}{|c|c|c|c|c|}
\hline \multicolumn{5}{|c|}{ Viḷani } \\
\hline \multirow[b]{2}{*}{ Year } & \multicolumn{4}{|c|}{ soil type-loam } \\
\hline & pH KCl & $\begin{array}{c}\text { Organic } \\
\text { matter, \% }\end{array}$ & $\begin{array}{c}\mathrm{K}_{2} \mathrm{O} \\
\mathrm{mg} \mathrm{kg}{ }^{1}\end{array}$ & $\begin{array}{c}\mathrm{P}_{2} \mathrm{O}_{3} \\
\mathrm{mg} \mathrm{kg}{ }^{1}\end{array}$ \\
\hline 2018 & 6.6 & 4.1 & 112 & 83 \\
\hline 2019 & 6.5 & 2.6 & 104 & 56 \\
\hline 2020 & 6.1 & 3.5 & 94 & 51 \\
\hline \multicolumn{5}{|c|}{ Stende } \\
\hline \multirow[b]{2}{*}{ Year } & \multicolumn{4}{|c|}{ soil type - clay sand } \\
\hline & pH KCl & $\begin{array}{c}\text { Organic } \\
\text { matter, \% }\end{array}$ & $\begin{array}{c}\mathrm{K}_{2} \mathrm{O} \\
\mathrm{mg} \mathrm{kg-}^{-1}\end{array}$ & $\begin{array}{c}\mathrm{P}_{2} \mathrm{O}_{3} \\
\mathrm{mg} \mathrm{kg-}{ }^{1}\end{array}$ \\
\hline 2018 & 5.6 & 3.1 & 216 & 166 \\
\hline 2019 & 6.3 & 2.8 & 244 & 125 \\
\hline 2020 & 7.0 & 2.2 & 151 & 361 \\
\hline
\end{tabular}

The conditions for growing soybeans were more favourable in Vilani - the soils have a significantly higher organic matter content, cly structure and optimal soil acidity. In Stende, soils have a lower content of organic matter, clay sand structure, soil acidity varies from year to year, 2018 - significantly below optimal.

Evaluation of soybeans yield and quality was made at four different fertilization backgrounds: Control - without additional fertilization, PK - basic fertilizer NPK 0- 45-75 (without nitrogen), NPK - basic fertilizer NPK 15-45-75, NPK+N20 - basic fertilizer NPK 15-45-75 and additional fertilizer N20 pure $\mathrm{kg} \mathrm{ha}^{-1}$. The fertilizer is applied to the soil before sowing by cultivating the soil.

\section{Climate data}

Sum of monthly precipitation showed in table 2. and temperature at both locations during the growing season showed in Figure 1.

TABLE 2 MONTHLY PRECIPITATION DURING THE GROWING SEASON AT THE EXPERIMENTAL SITES FROM 2018 TO 2020

\begin{tabular}{|c|c|c|c|c|c|c|}
\hline Year & 完 & $\stackrel{\vec{\pi}}{\Sigma}$ & $\stackrel{\Xi}{\Xi}$ & 로 & 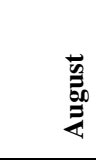 & ڤँ \\
\hline Sites & \multicolumn{6}{|c|}{2018} \\
\hline Stende & 47.7 & 14 & 28.5 & 32.6 & 94.1 & 52.8 \\
\hline \multirow[t]{2}{*}{ Vilani } & 27.5 & 13.6 & 42.3 & 35.4 & 93.0 & 29.4 \\
\hline & \multicolumn{6}{|c|}{2019} \\
\hline Stende & 8.4 & 30.7 & 52.1 & 117 & 21.1 & 50.7 \\
\hline \multirow[t]{2}{*}{ Vilani } & 0.0 & 69.8 & 48.4 & 92.9 & 105.4 & 63.2 \\
\hline & \multicolumn{6}{|c|}{2020} \\
\hline Stende & 20.3 & 37.3 & 42.7 & 60.2 & 33.9 & 32.4 \\
\hline Vilani & 27.1 & 84.7 & 73.1 & 66.3 & 60.0 & 43.3 \\
\hline \multicolumn{7}{|c|}{ Long term date } \\
\hline Stende & 36 & 50 & 71 & 89 & 88 & 62 \\
\hline Vilani & 32 & 52 & 75 & 81 & 71 & 62 \\
\hline
\end{tabular}

In all three vegetation seasons, the sum of active temperatures was similar - close to $2000^{\circ} \mathrm{C}$, however, for example, in 2018 this amount was reached in 117 days, and in 2019 - in 135 days.

In 2018, soybean productivity was adversely affected by the lack of precipitation (in Stende, the amount of precipitation during the growing season reaches only 157 $\mathrm{mm}$ ). In 2019, the development of soybeans was limited by temperatures, which were significantly below the norm in several periods of soybean development (especially during germination and flowering). Several later soybean varieties suffered from autumn frosts before ripening.

Very low air temperatures were observed in May of 2020, which hindered the development of soybeans, and some of the soybean seedlings died. The growing season from August to October was favourable for the development of soybeans. 
Environment. Technology. Resources. Rezekne, Latvia Proceedings of the $13^{\text {th }}$ International Scientific and Practical Conference. Volume 1, 101-107

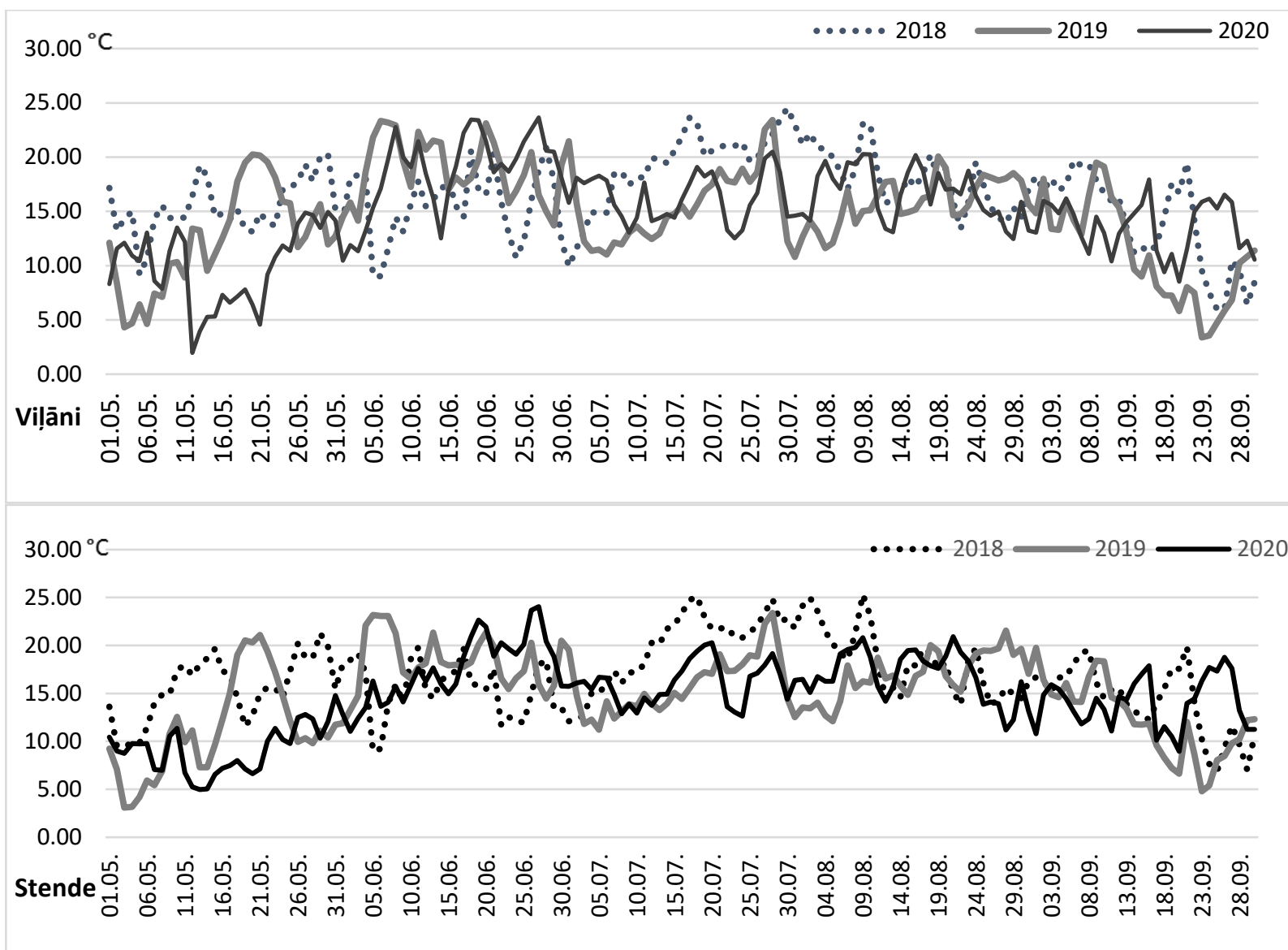

Fig. 1. Mean air temperature ( $2 \mathrm{~m}$ above ground level) in the experimental sites.

The vegetation period from sowing to maturity in Stende varied from 108 days ('Laulema', 2018) to 142 days ('Lajma', 2019) and from 120 days ('Laulema', 2018) to 161 days ('Lajma', 2019). The sum of active temperatures of vegetation period assumed from $1889^{\circ} \mathrm{C}$ ('Laulema', 2018) to $2173^{\circ} \mathrm{C}$ ('Lajma', 2018) in Stende and from $2003^{\circ} \mathrm{C}$ ('Laulema', 2020) to $2231^{\circ} \mathrm{C}$ ('Lajma', 2018) in Vilani. The sum of precipitation from sowing to maturity in Stende varied 156mm ('Laulema', 2018) to 263 mm ('Lajma', 2019) and from 186 mm ('Laulema’, 2018) to 426 mm ('Lajma', 2019) in Vilani.

Soybeans was harvested at the GS90-99, using compact gain harvester Wintersteiger, then dried and cleaned using MiniPetkus equipment, determined humidity. Yield was calculated as $\mathrm{t} \mathrm{ha}^{-1}$ at humidity $14 \%$ and $100 \%$ purity. Impact of cultivation technologies was evaluated comparing yield, thousand grain weight, number of pods per plant, number of plants per $1 \mathrm{~m}^{2}$, and chemical composition of seeds based on average values of both cultivars. Number of pods per plant was determined as average of 20 plants from each replications. Indicators of productivity was measured for each of 4 replications and mean value was calculated.

For quality traits $0.5 \mathrm{~kg}$ soybean seeds was complected. Test weight, protein, fat and fibre of harvested soybeans were made in duplicate. Measures of quality traits are given in dry matter.

The chemical analyses were carried out at the Laboratory of Cereal Technology and Agricultural Chemistry of the Institute of Agricultural Resources and Economics. Collected soybean seed samples of each replicates were dried at $60^{\circ} \mathrm{C}$, ground in mill with a 1.0 $\mathrm{mm}$ sieve and collected for further analysis. Protein content was determined by the Kjeldahl method, and conversion factor 6.25 was used to convert total nitrogen to crude protein. Fat was extracted with petroleum ether (boiling range of $40-60^{\circ} \mathrm{C}$ ) by the Soxhlet extraction method and determined gravimetrically. Content of fibre was determined by ISO 5498:1981[7].

Statistical analysis. The obtained results were statistically processed using methods of descriptive statistics (sample mean and standard deviation) and factor analysis (Anova: Two-Factor Without Replication and General Linear Model - Univariate) at MS Excell IBM SPSS 20 programs. Statistical significance was declared at $p<0.05$.

\section{RESULTS}

The results of study confirms that climatic conditions significantly affected amount and productivity of soya 
bean yield. According to most of studies [8], [9], [10] the site conditions primarily the amount and distribution of rainfall significantly modify harvested quantity and quality of soybeans. Among other factors including cultivation technology, these climatic conditions are the most difficult to control and they are greater limiting factors in the maximum yield [8].

Yield of harvested soybeans from all trials in Vilani in different years are showed in Figure 2, but in Stende in Figure 3.

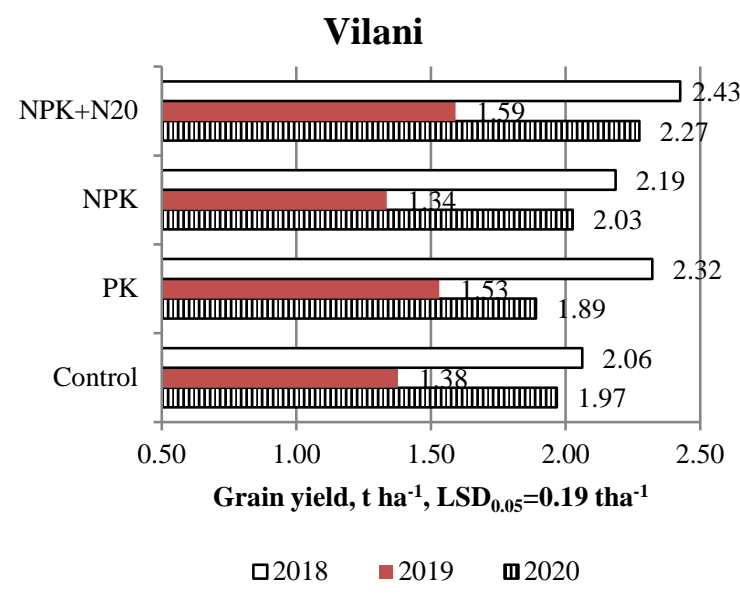

Fig. 2. Yield of soybeans of experimental site Vilani

The soil of experimental fields in Vilani characterized with higher level of organic matter, therefore fertilizers do not have an effect on productivity. Significant increase of soybean yield was obtained from variant PK (2.32 t ha-1) in 2018 year when was relatively few precipitation, providing plants with phosphorus and potassium fertilizers. Additional increase of nitrogen NKP+N20 resulted in the increase of yield $\left(2.32 \mathrm{t} \mathrm{ha}^{-1}\right)$ in comparison with control (2.06 t ha-1) but not with yield from fields where fertilizer background was PK (without additional nitrogen).

Climatic conditions in 2019 - rainfall prior maturity and early autumn frosts - significantly effected harvesting of soybeans and caused additional crop losses, as a result insignificant differences among variants were calculated ( $>0.05$ ), although trends were the same as in 2018, described above. The results of year 2020 showed significant difference of yield from control fields $(1.97 \mathrm{t}$ $\mathrm{ha}^{-1}$ ) and variant NPK+N20 (2.27 t ha-1).

Summarizing the above - additional nitrogen not always is important in fields with high content of organic matter (as in Vilani). It is important to evaluate provision of other nutrients and additional provision of soil with phosphorus and potassium fertilizers also could give significant increase of yield.

Many field data showed that the total amount of $\mathrm{N}$ assimilated in a plant shoot is highly correlated with the soybean seed yield [10], [11]. Morshead et. al. concluded that nitrogen application progressively and significantly increased the yield of soybean up to the $\mathrm{N}$ rate of $26.45 \mathrm{~kg}$ $\mathrm{ha}^{-1}$ where the highest seed yield of soybeans was obtained [11]. Fertilizing with $30 \mathrm{~kg} \mathrm{~N} / \mathrm{ha}$ was the optimal rate both in terms of quality and quantity of the yield, as well as economically. The varieties of 'Aligator' and 'Lissabon' proved the best suited to the climate and environment of Głubczyce region, regarding significant LSD coefficients [10].

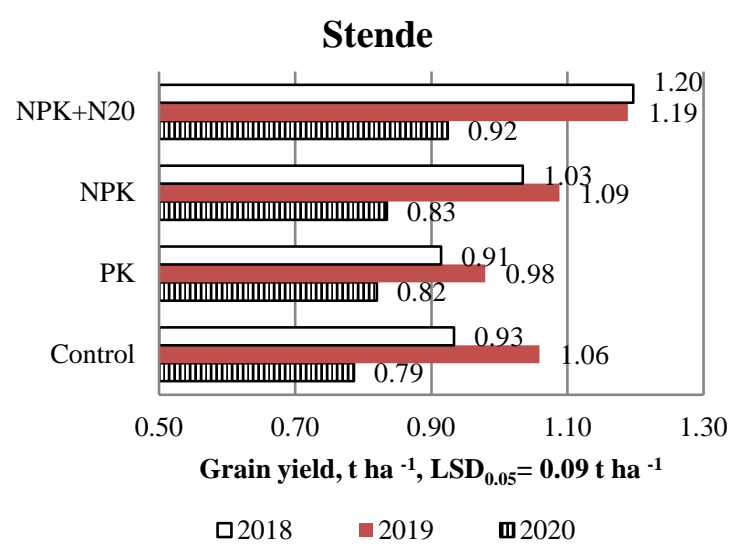

Fig. 3. Yield of soybeans of experimental site Stende

Experimental fields in Stende organized in fields with soil characterized with relatively low content of organic matter, but relatively high content of phosphorus and potassium. Additional nitrogen amount could significantly increase soybean yield especially in less fertile soils [11], [12] and especially in the early stages of plant development when on roots were not developed Rhizobium bacteria.

Soil type - clay sand, like in Stende, characterized with relatively low soil $\mathrm{pH}(5.6$ - 6.3). Weakly acidic soil reaction, low soil temperatures or drought were main factors negatively affected operation of Rhizobium bacteria. Additional nitrogen in this kind of conditions showed significant impact on soyabean yield. The results of field trials in Stende in 2018 and 2020 showed significantly higher yield of soybeans in variants NPK (1.03 tha $\mathrm{th}^{-1}$ in 2018 and $0.83 \mathrm{t} \mathrm{ha}^{-1}$ in 2020) and NPK+N20 (1.20 t ha-1 in 2018 and $0.92 \mathrm{t} \mathrm{ha}^{-1}$ in 2020) in comparison with control where yield was $0.93 \mathrm{t} \mathrm{ha}^{-1}$ in 2018 and $0.72 \mathrm{t}$ ha $^{-1}$ in 2020, respectively. Evaluation of yield in 2019 showed significant difference just in variant NPK+N20 (1.19 $\left.\mathrm{t} \mathrm{ha}^{-1}\right)$ in comparison with control (1.06 t ha-1).

Summarizing the results in Stende - additional nitrogen dose has been useful if environmental conditions are not favorable for development of nodules on the soybean roots, but additional phosphorus and potassium in soil rich with them was not effected yield significantly.

Since crop productivity indicators determines TGM, number of pods per plant and number of plants per $1 \mathrm{~m}^{2}$, these parameters of soya bean harvested in this study showed in table 3 . 
TABLE 3 SOYBEAN PRODUCTIVITY INDICATORS AGAINST THE BACKGROUND OF DIFFERENT FERTILIZER RATES

\begin{tabular}{|c|c|c|c|c|c|}
\hline $\begin{array}{l}\text { Indi- } \\
\text { cators }\end{array}$ & Variant s & 2018 & 2019 & 2020 & Mean \\
\hline \multirow{10}{*}{ TGM, g } & \multicolumn{5}{|c|}{ Stende, $L D_{0.05}=5.9 \mathrm{~g}$} \\
\hline & Control & 158.3 & 172.0 & 162.8 & 164.7 \\
\hline & PK & 156.5 & 173.7 & 160.5 & 164.2 \\
\hline & NPK & 165.5 & 174.1 & 163.0 & 167.5 \\
\hline & $\mathrm{NPK}+\mathrm{N} 20$ & 171.9 & 181.1 & 163.9 & 172.3 \\
\hline & \multicolumn{5}{|c|}{ Vilani, $L D_{0.05}=5.4 \mathrm{~g}$} \\
\hline & Control & 154.1 & 159.4 & 158.2 & 157.3 \\
\hline & PK & 163.1 & 166.0 & 157.2 & 162.1 \\
\hline & NPK & 169.2 & 166.7 & 162.6 & 166.1 \\
\hline & $\mathrm{NPK}+\mathrm{N} 20$ & 166.1 & 172.9 & 166.2 & 168.4 \\
\hline \multirow{10}{*}{$\begin{array}{l}\text { Number } \\
\text { of pods } \\
\text { per plant }\end{array}$} & \multicolumn{5}{|c|}{ Stende, $L D_{0.05}=6.2$ plants } \\
\hline & Control & 23.1 & 44.9 & 20.4 & 29.5 \\
\hline & PK & 24.9 & 42.9 & 20.2 & 29.4 \\
\hline & NPK & 26.5 & 47.3 & 24.0 & 32.6 \\
\hline & $\mathrm{NPK}+\mathrm{N} 20$ & 26.8 & 57.1 & 23.0 & 35.7 \\
\hline & \multicolumn{5}{|c|}{ Vilani, $L D_{0.05}=3.7$ pods } \\
\hline & Control & 22.6 & 30.5 & 27.8 & 27.0 \\
\hline & PK & 21.7 & 31.3 & 27.6 & 26.8 \\
\hline & NPK & 21.0 & 31.6 & 33.8 & 28.8 \\
\hline & $\mathrm{NPK}+\mathrm{N} 20$ & 23.3 & 31.0 & 29.7 & 28.0 \\
\hline \multirow{10}{*}{$\begin{array}{l}\text { Number } \\
\text { of plants } \\
\text { per } 1 \mathrm{~m}^{2}\end{array}$} & \multicolumn{5}{|c|}{ Stende, $L D_{0.05}=2.4$ plants } \\
\hline & Control & 25.8 & 15.4 & 30.5 & 23.9 \\
\hline & PK & 28.1 & 15.4 & 29.6 & 24.4 \\
\hline & NPK & 26.0 & 17.3 & 31.0 & 24.7 \\
\hline & $\mathrm{NPK}+\mathrm{N} 20$ & 25.9 & 14.4 & 31.5 & 23.9 \\
\hline & \multicolumn{5}{|c|}{ Vilani, $L D_{0.05}=5.2$ plants } \\
\hline & Control & 49.5 & 43.5 & 39.5 & 44.2 \\
\hline & PK & 47.5 & 46.5 & 41.5 & 45.2 \\
\hline & NPK & 42.5 & 41.5 & 43.0 & 42.3 \\
\hline & $\mathrm{NPK}+\mathrm{N} 20$ & 49.5 & 44.0 & 39.5 & 44.3 \\
\hline
\end{tabular}

The sowing rate was 50 germinating seeds per $\mathrm{m}^{2}$. Number of productive plants per $\mathrm{m}^{2}$ among years differed. It was significantly affected by climatic conditions. After sowing in the 2018 prolonged drought, in 2019 and 2020 years prolonged low temperatures of air and soil. The lowest germination was in Stende, for example in 2019 it was $31 \%$ of planned - average 15.6 plants per $\mathrm{m}^{2}$.

Next indicator characterized a productivity of soya beans are number of seeds per pod and 1000 grain weight. An increase of nitrogen amount was not significantly affected number of pods per plant. The number of pods, along with increasing fertilizer rate was increased in
Stende from 29.4 (PK) to 35.7 (NPK+N20) and from 26.8 (PK) to 28.8 (NPK) in Vilani, but analysis of variance showed that critical value is higher than differences among variants. This indicator was significantly affected by climatic conditions of year - determination coefficients in Stende $\mathrm{R}^{2}=92 \%$, in Vilani $\mathrm{R}^{2}=79 \%$. Variation of years in Stende was average from 21.9 (2018) to 48.1 (2019) and in Vilani from 22.1 (2018) to 31.1 (2019).

Similar data obtained evaluating average number of seeds per pod. It was significantly affected by year (number of seeds per pod in Stende varied from 2.82 to 3.4 , determination coefficients in Stende $\mathrm{R}^{2}=79 \%$, in Vilani it was lower and varied from 1.38 to1.53, $\mathrm{R}^{2}=69 \%$ ) but differed insignificantly by fertilizer rates ( $>0.05)$.

Increase of fertilizer rate was significantly increased TGM of soybeans in both sites. TGM was obtained significantly higher $(\mathrm{p}<0.05)$ in Vilani in all years in variants NPK (169.2g, 166.7g and 162.6g) and NPK+N20 (166.1g, 172.9g and 166.2g) in comparison with control fields - 154.1g, 159.4g and 158.2g, respectively. This indicator was significantly higher also in 2018 (163.1g) and 2019 (166.0g) in samples of fields where fertilizer rate was PK (without surplus nitrogen) in comparison with control, but then it was insignificantly differed from averages of samples from fields with mentioned fertilizer rates with using of addition nitrogen.

TGM was determined significantly higher - 171.9g, $181.1 \mathrm{~g}$ and $163.9 \mathrm{~g}$ in samples of fields with the highest fertilizer rate $\mathrm{NPK}+\mathrm{N} 20\left(15+20 \mathrm{~kg} \mathrm{~N} \mathrm{ha}^{-1}\right)(\mathrm{p}<0.05)$ in comparison with control - 158.3g, 172.0g, 162.8g relatively. The average TGM obtained in Stende was higher as obtained in Vilani, but total yield of harvested soybeans was not higher because significantly smaller number of plants per $\mathrm{m}^{2}$. From other side smaller competition among plants in Stende give higher number of pods per plant and higher TGM, but it was not compensate decrease of yield caused by unsprouting plants.

Our results of variant with higher nitrogen fertilizer rate $(\mathrm{NPK}+\mathrm{N} 20)$ were in line with results of Morshed et.al., who concluded from a pot experiment that nitrogen application progressively and significantly increased the yield of soybean [11]. Bobrecka-Jamro et. al. study also observed that plants from the control treatment (without nitrogen fertilizer) were characterized by smallest number of pods and TGW [12].

The chemical composition of soybeans significantly differed $(p<0.05)$ among years at both experimental sites, but impact of cultivation technologies was not expressed. The same conclusion was reported by Vollmann et.al., after evaluation of 60 soybean genotypes of early maturity groups - average to high protein content (range 399-476 g $\mathrm{kg}^{-1}$ ) was found in years with high air temperature and moderate rates of rainfall during the seed filling period, whereas seed protein content was drastically reduced (range 265-347 $\mathrm{g} \mathrm{kg}^{-1}$ ) in seasons of insufficient nitrogen 
fixation or higher amount of precipitation during seed filling [13].

Protein content of soybeans harvested at Stende and Vilani showed at figure 4.
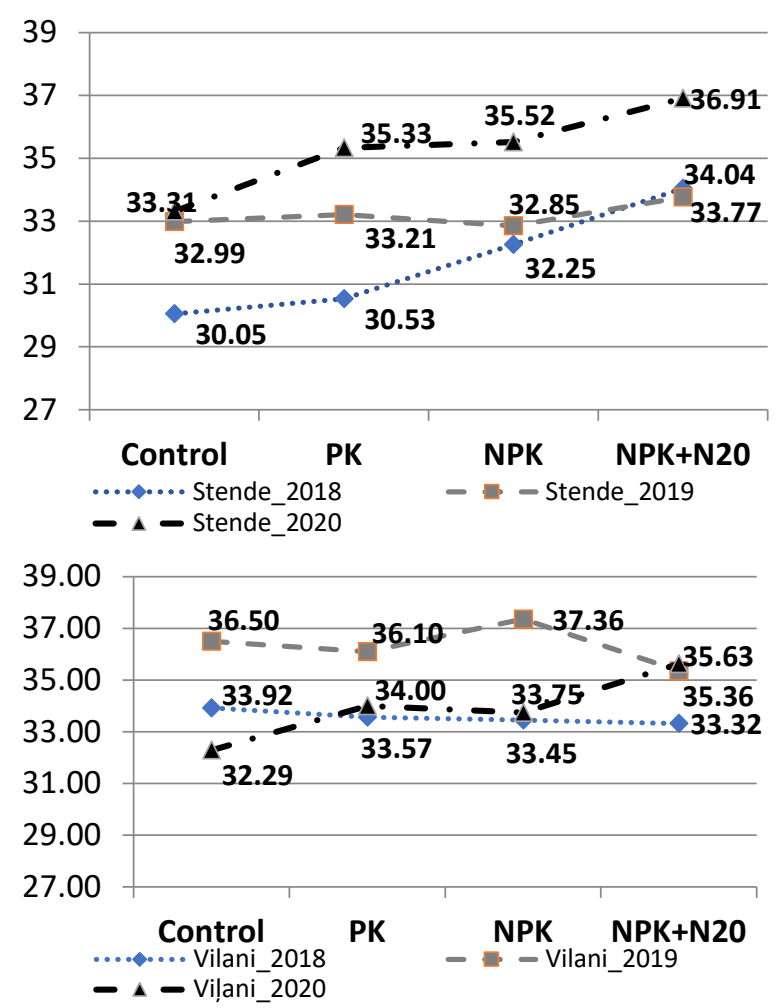

Fig.4. Protein content of soybeans grown in Stende and Vilani from 2018 to 2020 year.

There was observed tendency when protein content of samples from fields with fertilization background $\mathrm{NPK}+\mathrm{N} 20$ was higher than protein content of soybeans from control group. Significant difference among fertilizer rates was determined at Stende $(\mathrm{p}-=0.04<0.05)$, but not in Vilani $(p=0.90>0.05)$. The results in Stende was significant in 2018 when protein content of samples from fields with additional nitrogen dose determined 34.04\% in comparison with control 30.05\% ( $<<0.05)$ (13\% higher) and in 2020 when protein content determined $36.9 \%$ and $33.31 \%(p<0.05)(11 \%$ higher as control), respectively. Same tendency was observed in Vilani just in 2020 where protein content of control group samples determined $32.29 \%$ but protein content of samples from fertilization background NPK +N20 with additional nitrogen (35 kg per ha) - 35.63\% (10\% higher) and this difference was significant $(\mathrm{p}<0.05)$.

These results regarding on protein content was in line with investigation of Bobrecka-Jamro et.al., where concluded that high doses of nitrogen increased the content of total protein in seeds and decreased the content of crude fat, as well as causing a significant decrease in the content of ash and fibre in seeds [12]. Obtained protein content of control group (additional nitrogen $\mathrm{N}=0 \mathrm{~kg}$ ha ${ }^{1}$ ) soybean seeds in mentioned study was $35.42 \%$, but protein content of experimental groups $36.3 \%(\mathrm{~N}=30 \mathrm{~kg}$ $\left.\mathrm{ha}^{-1}\right)$ and $36.96 \%\left(\mathrm{~N}=60 \mathrm{~kg} \mathrm{ha}^{-1}\right)$. Difference of protein content in control group soybeans and experimental group was $2-4 \%$ in the study of Bobrecka-Jamro et.al. Morshed et al. concluded that nutrient uptake and protein content in seeds increased with increasing levels of $\mathrm{N}$ (up to rate $26.45 \mathrm{~kg} \mathrm{~N} \mathrm{ha}^{-1}$ )[8]. In contrast, results of Ferreira et.al., showed that fertilization with nitrogen no effect and Valinejad et.al. studies finded insignificant effect on total protein and crude fat in soya beans [14], [15]. The results of soybeans fat and fibre content of our study assumed in table 4.

TABLE 4 THE FAT AND FIBRE CONTENT OF SOYBEAN GROWED IN STENDE AND VIANI

\begin{tabular}{|c|c|c|c|c|c|}
\hline $\begin{array}{l}\text { Indi- } \\
\text { cators }\end{array}$ & Variant s & 2018 & 2019 & 2020 & Mean \\
\hline \multirow{10}{*}{ Fat, \% } & \multicolumn{5}{|c|}{ Stende } \\
\hline & Control & 23.11 & 19.08 & 20.33 & 20.84 \\
\hline & PK & 22.73 & 18.89 & 20.64 & 20.75 \\
\hline & NPK & 21.58 & 19.00 & 20.97 & 20.51 \\
\hline & $\mathrm{NPK}+\mathrm{N} 20$ & 21.74 & 16.79 & 20.92 & 19.82 \\
\hline & & & ilani & & \\
\hline & Control & 20.18 & 17.28 & 19.14 & 18.87 \\
\hline & PK & 20.71 & 17.18 & 18.81 & 18.90 \\
\hline & NPK & 20.36 & 17.23 & 19.54 & 19.04 \\
\hline & $\mathrm{NPK}+\mathrm{N} 20$ & 20.48 & 17.96 & 19.42 & 19.29 \\
\hline \multirow{10}{*}{ Fibre, \% } & \multicolumn{5}{|c|}{ Stende } \\
\hline & Control & 12.68 & 10.76 & 10.83 & 11.42 \\
\hline & PK & 12.59 & 11.15 & 10.72 & 11.49 \\
\hline & NPK & 12.93 & 11.16 & 10.91 & 11.67 \\
\hline & $\mathrm{NPK}+\mathrm{N} 20$ & 10.87 & 13.25 & 10.78 & 11.63 \\
\hline & \multicolumn{5}{|c|}{ Vilani } \\
\hline & Control & 11.52 & 11.33 & 9.68 & 10.85 \\
\hline & $\mathrm{PK}$ & 11.39 & 11.54 & 9.94 & 10.96 \\
\hline & NPK & 11.23 & 11.64 & 7.94 & 10.27 \\
\hline & $\mathrm{NPK}+\mathrm{N} 20$ & 11.25 & 11.75 & 9.13 & 10.71 \\
\hline
\end{tabular}

Evaluation of soybean fat and fibre content in both experimental sites showed that there is not significant difference among fertilizer rates in our study. Regarding fat content observed tendency when fat content decrease with increasing nitrogen fertilizer in samples of Stende, similar with results of other studies [8], [12], [13]. This tendency was more pronounced in 2018 year when fat content of control determined $23.11 \%$, but fat content of soybean samples from variant NPK+N20 - 21.74\% (6\% lower than control). The impact of year on fat content of soybeans was significant $(\mathrm{p}<0.05)$ as in Stende, same as in Vilani. Vollmann et.al., reported that fat content in years with high protein content varied from $17.44 \%$ to $19.67 \%$, 
but in years with lower protein content from $21.13 \%$ to $24.84 \%$ [13].

The results of soybeans fibre content significantly differed $(\mathrm{p}<0.05)$ among years, but did not show any tendency. Average fibre content in Stende for all fertilization backgrounds were $11.42 \%, 11.49 \%, 11.67 \%$ and $11.63 \%$. There are few reports regarding fibre content of soybean seeds and factors affected it, but data mentioned in USDA data base reported average fibre content 9.7\% [16]. Bobrecka-Jamro et.al., reported, that fibre content decreased from $5.81 \%$ to $5.49 \%$ if nitrogen fertilizer increased from 0 (control) to $\mathrm{N}=60 \mathrm{~kg} \mathrm{ha}^{-1}$ ) [12]. Our conclusion is that fibre content is much stronger affected by other factors, for example precipitation and humidity of soil than nitrogen content.

\section{CONCLUSIONS}

The results of study confirms that soybean productivity is significantly affected by meteorological conditions during the growing season, soil fertility and cultivation technology. Additional nitrogen fertilizers (up to $30 \mathrm{~kg} \mathrm{~N}$ $\mathrm{ha}^{-1}$ ) significantly affected soybean yield if the soil is low in organic matter content, or environmental conditions are not favourable for the activity of Rhizobium bacteria.

The application of additional fertilizer significantly affected the increase of soybean 1000 seed weight (TGM), but did not affect such plant productivity indicators as the number of pods per plant, the number of seeds per pod.

The addition of fertilizer had a positive effect on the protein content of soybeans in less fertile soils, but did not have a significant effect in the soybean trial, which was set up in soils with high organic matter content in Vilani. The fat and fibre content of soybeans was not affected by applied fertilizer rates.

\section{REFERENCES}

[1] EIP AGRI report, 2014.

[2] https://www.lad.gov.lv/lv/statistika/platibu-maksajumi/periods2004-2016/statistikas-dati-par-2019-gadu

[3] Eurostat, 2019.[online] Available :

https://ec.europa.eu/eip/agriculture/en/publications/eip-agri-focusgroup-protein-crops-final-report

[4] C. M. Grieshop and G. C. Fahey. "Comparison of quality characteristics of soybean meals,” J. Agric. Food Chem., vol. 60, pp. 437-442, 2001.

[5] C. M. Grieshop, C. T. Kadzere., G. M. Clapper, E. A. Flickinger, L. L. Bauer, R. L. Frazier and G. C. Fahey Jr.. "Chemical and nutritional characteristics of United States soybeans and soybean meals,” J. Agric. Food.Chem., vol. 51, pp.7684-7691, 2003.
[6] J. Board and C. S. Kahlon, Soybean yield formation: What controls it and how it can be improved in Soybean Physiology and Biochemistry, pp. 1-36, November, 2011.

https://www.researchgate.net/publication/221918892_Soybean_Yi eld_Formation_What_Controls_It_and_How_It_Can_Be_Improve d [Acessed Marth 20, 2021] DOI: $\underline{10.5772 / 17596}$

[7] ISO 5498:1981. Agricultural food products. Determination of crude fibre content. ISO/TC34, ICS: 67.050, ed.1, 8 pp.

[8] A. M. H. de Avila., J. R. B. Farias, H. S. Pinto, F. G. Pilau, "Clmatic restrictions for maximizing soybean yields," in A comprehensive Survey of International Soybean ResearchGenetics, Physiology, Agronomy and Nitrogen Relationships pp.367-375, January 2, 2013. eBook (PDF) ISBN: 978-953-514259-1.

https://www.intechopen.com/books/a-comprehensive-survey-ofinternational-soybean-research-genetics-physiology-agronomyand-nitrogen-relationships/climatic-restrictions-for-maximizingsoybean-yields [Acessed Marth 20, 2021]

[9] V. Popovic, M.Tatič, V. Sikora, J. Ikanovic, G. Drazic, V.Dukič, B. Mihailovic, V. Filipovic, G.Dozet, L. Jovanovic and P. Stevanovic "Variability of yield and chemical composition in soybean genotypes grown under different agroecological conditions of Serbia” Romanian Agr.Res., No 33, pp. 29-39, 2016.

[10] M. Bednarczyk, I. Pisarek "Sustainable development for soya production based on the field research carried out at the Variety assessment experimental station of Glubczyce in the years 20152017”, Economic and Environmental Studies, vol 18, no 4., pp.1219-1234, April 2019,

https://www.researchgate.net/publication/332555939 [Acessed Marth 20, 2020]

DOI: https://doi.org/10.25167/ees.2018.48.3

[11] R. M. Morshed, M. M. Rahman and M.A.Rahman "Effect of nitrogen on seed yield, protein content and nutrient uptake of soybean (Glycine max L.), ’ J.Agric Rural Dev, vol. 6 (1\&2), pp.1317, June 2008. http://www.banglajol.info/index.php/jard [Accessed Marth 15, 2021] DOI: 10.3329/jard.v6i1.1652

[12] D. Bobrecka-Jamro, W. Jarecki and J. Buczek "Response of soya bean to different nitrogen fertilization levels," J. Elem., vol. 23 (2), pp. 559-568, 2018. Ütiski DOI: 10.5601/jelem.2017.22.3.1435

[13] J.Vollmann, C. N. Fritz, H. Wagentristi and P. Ruckenbauer "Environmental and genetic variation of soybean seed protein content under Central European growing condtions” J. Sci. Food Agric. Vol 80, pp.1300-1306, 2000.

[14] A. S. Ferreira, A.A., Balbinot Jr., F. Werner, C. Zucareli, J. C. Franchini and H.Debiasi "Plant density and mineral nitrogen fertilization influencing yield, yield components and concentration of oil and protein in soybean grains,” Bragantia vol.75 (3), pp. 362370, June 23, 2016.

https://www.scielo.br/scielo.php?script=sci arttext\&pid=S000687052016000300362 [Acessed Marth 20, 2021]

https://doi.org/10.1590/1678-4499.479

[15] M. Valinejad, S. Vaseghi, and M. Apzali, "Starter nitrogen fertilizer impact on soybean yield and quality,"int. J. Eng. Adv. Tech., vol. 3(1), pp.333-337, October2013. https://www.ijeat.org/wpcontent/uploads/papers/v3i1/A2250103113.pdf

[16] USDA (2018) United States Department of Agriculture Food Composition Databases. [Online]. Available: https://www.nal.usda.gov/fnic/databases. [Acessed 30.04.2020.] 